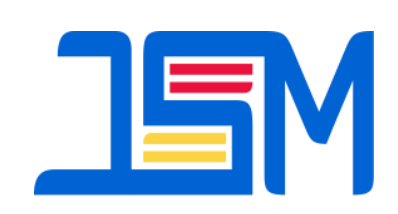

Jambura Science Of Management
JAMBURA SCIENCE OF MANAGEMENT

Homepage : http://ejurnal.ung.ac.id/index.php/jsm

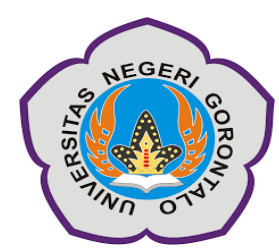

\title{
Fraud Pentagon in The Act of Cheating Financial Statements With The M- Score Method
}

\author{
Adi Susilo ${ }^{1}$, Endang Masitoh ${ }^{2}$, Suhendro Suhendro ${ }^{3}$ \\ ${ }^{1,2,3}$ Faculty of Economics, Universitas Islam Batik Surakarta \\ Jl. KH. Agussalim No. 10 Postal Code 57147 Surakarta. \\ Email: adism1407@gmail.com
}

\begin{abstract}
:
Fraudulent financial statements include a number of ways of doing, to benefit from others by mis-presenting material in financial statements. The purpose of this research is to test and lysis influence pressure, opportunity, rationalization, competence, and arrogance on the financial statements of transportation, toll roads, airports and ports listed on the Indonesia Stock Exchange (IDX) period 2015-2018, with a sample count of 52 where data collection is carried out by purposive sampling method. This type of quantitative research with case studies, data analysis method uses logistics regression analysis with spss program version 17 . The results showed arrogance had an effect on financial report fraud while variable pressure, opportunity, rationalization, and competence had no effect on financial report fraud. Further research can increase the number of research samples so that the results of the research can represent all service companies.
\end{abstract}

\section{Keywords: Pressure; Opportunity; Rationalization; Competence; Arrogance; Fraud}

Financial statements are used as information providers regarding financial position, financial performance and changes in the company's financial position. Financial report information describing the company's performance, beneficial to internal and external companies. Rahmanti, (2013) Importance of financial statements for the company, the management strives to present a financial report describing the good performance of the company.
The cheating financial statements are intentional actions and the company's resources are unreasonable to gain personal luck. Fraudulent financial statements cause irrelevant information and cause mismanagement of the material. Damayanti (2017) cheating generally occurs due to pressure to commit abuses, the urge to exploit the opportunity and the justification of the action of fraud. 
The expansion of the fraud Triangle Model Cressey (1953) Cheating action has evolved the way coverage. Pentagon model developed Marks (2012) Crowe Horwarth USA LLP. Crowe fraud Pentagon added two factors according to the organizational development of arrogance and competence, these two factors are able to menjadi kontrol internal organisasi mencegah kecurangan.

The Association Of Certified Frau Examineres (ACFE) declared fraud globally in the year 2014 to reach $4 \$ 3.5$ trillion. The cheating company Enron who boosted profits and concealed debt of more than $\$ 1$ billion by using the company outside of bookkeeping (off-the-books partnership) manipulating the Texas market involving foreign officials to win contracts (Marks et al., 2014).

In the concept of the relevance of the value of cheating financial statements in Indonesia by the state Owned enterprises (BUMN), Garuda Indonesia Flight Service company presenting financial report period 2018 that does not comply with the company's condition. The company displays a higher profit while the company is losing money. The company conducts the registration of revenues agreement of US $\$ 239,940,000$ but the client has not paid any payment. 2018 period financial balance is negative, the statement of Financial Accounting Standard (PSAK) is recognized after the proof of the validity of the payment.

Research conducted Zaki (2017) Advantages of triangular model fraud and Diamon model in assessing financial statements fraudulent financial, the decision to commit fraud action based on the interaction of the Triangle Model Incentive, opportunity and rationality. The triangle factor model is able to improve the volatility of auditors predicting, analyzing, and recommendations on financial report fraud.

Many cases of fraudulent financial statements, requiring detection are capable of knowing the indication of fraud or manipulation. The detection of earning manipulation Massod (1999) explains the company's differences in manipulator and non-manipulator companies public. The occurrence of fraudulent financial statements has an indication of drastic improvement on receivables, worsening of gross margin, decreased assets, sales growth, and increased accruals.

Another research conducted by Kinanti (2018) which states Benish M-score is able to properly detect the act of cheating banking companies. This research proved the banking samples that occurred greater fraud than in the banking samples that did not occur cheating

Financial fraud is an intentional element and omission of data presentation is not in accordance with the accounting standards that apply to influence the decision of the interested parties. Sekar (2018) fraud Pentagon in fraud detection into a filter of cheating actions. Management as an internal controller and policy handler reduces the action of cheating especially in an organizational environment.

The number of financial report fraud on a national and international scale encourages companies to take early control and detection. Fraud in the field of services is more vulnerable, in previous research samples in the field of services have not 
made a logical contribution and represent the field of services.

Based on the company's fraudulent actions for various reasons, it requires detection and supervision. The fraud detection of financial statements is becoming an early attempt at reducing asset misuse and profit management abuse. Preventive analysis and fraud detection techniques are able to provide a logical basis to determine which areas are focused attention and demonstrate fraud.

\section{METHOD}

This research is a type of quantitative study. This Research uses Secondary data. The data source is derived from the financial statements of sub-sector services, toll roads, airports, and ports in the Indonesia stock Exchange. The population in this research is a sub-sector service company, Toll Road, airport, and Port of Bura Securities Indonesia (IDX) period 2015-2018. Sampling techniques using purposive sampling method with the research criteria is the service company of transportation subsector, toll road, airport, and port listed on the Indonesia Stock Exchange in 2015-2018. Companies that do not submit annual financial statements and records of consecutive financial statements for three years as of 2015-2018. Financial statements not stated in the rupiah according to the required data in the research variables

The research methods used in case studies, by applying a theory of logistic regression models included match tests for data analysis. The data used is the secondary data obtained from www.idx.co.id. Analysis of test data against each hypothesis using SPSS version 17 for Windows.

\section{Variablel Research and operational definitions}

The variables in this study are:
a. Fraudulent financial statements (Y)
b. pressure (financial target) $\mathrm{X} 1$
c. Opportunity (Surveillance effectiveness) $\mathrm{X} 2$
d. Rationalization (change of auditor) X3
e. Competence (change of directors) X4
f. Arrogance (number of CEOs) X5

The operational definitions in this study can be described as follows:

a. Financial Fraud report (Y)

Changes in accounting principles are able to affect the amount, classification, presentation method and disclosure. Financial statement fraud is measured by a beneish $\mathrm{M}$-score, from the results classified between manipulator companies and non-manipulators. Fraud is measured using the M-Score Indexs.

b. Pressure (Target Finance)

The management or agents that run the company's activities are required to produce good performance and generate great profits, the financial pressures of making management report by manipulation (Scott, 2014). In this study the financial Target variables were measured with.

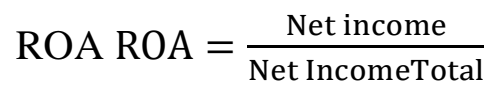

c. Opportunity (Effectiveness of surveillance) 
The emergence of fraud arises in the opportunity of objects, the space of movement of opportunities will be smaller if the monitor and oversight of the company is increasingly tight. Sekar (2018) mentions the existence of independent councils will generally provide wider and objective monitoring. In this variable the effectiveness of monitoring measured by BDOUT BDOUT $=\frac{\text { Number of independent Board of Commissioners }}{\text { Total Number of Commissioners }}$

d. Rationlization (Auditor changes)

The company in the rotation of Auditors meets government regulation No. 20 year 2015 Public accounting is limited in conducting auditors of historical financial statements of the company three years in succession Also. In this study the auditor's changes were measured with a Varibel Dummy, if the company underwent a change of auditor then was given a value of 0 , if the change in three years with the same auditor then was given a value of 1 .

e. Competence (Change of BOD)

Changes in the Board of Directors are explained in the financial statements of transferring authority in the resolutions of the general Meeting of Shareholders (GMS). The change of board of directors can occur because the results of GMS and company wishes resulted in improved performance in the previous year. In this study the change of directors was measured with Dummy variables in case of changes in the board of directors then given a value of 1 , if not subjected to changes given a value of 0.Arrogance (Jumlah CEO)

The level of the company's arrogance is shown profile of the CEO amount in the annual financial report. Tessa (2016) states the number of frequent image CEOS have an effect on the indication of fraud financial reporting. In this research the arrogance was measured by the large number of CEOS in the annual financial report.

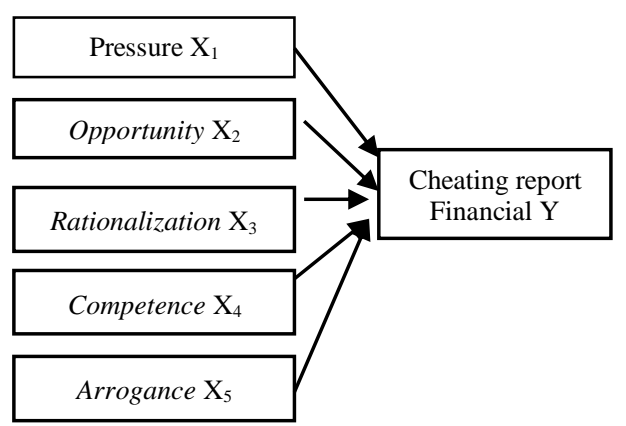

Figure 1. Hypothesis

Description:

Hypotheses in this study as follows :

H1 : Pressure (Financial targets) affect financial fraud.

$\mathrm{H} 2$ : Opportunnity (Effectiveness of surveillance) Negligence of financial statements.

H3 : Rationalizatio (Auditor changes) affect financial fraud.

H4 : Competence (Auditor changes) affect financial fraud.

H5 : Arrogance (Number of CEOS) to fraudulent financial statements. 


\section{RESULTS}

Logistical regression analyses are used because dependent variables are data in the form of dichotomy (classification). The dependent variables in this study are companies that conduct financial report fraud that is measured by a variable dichotomy 0 , companies that do not commit fraud are measured by the variable dichotomy 1. Regression analysis in this study with SPSS version 17.

Good logistic regression model regression model There is no noticeable difference between classification which is predicted with observed classification. Value hosmer and lemeshow goodness of fit test Measured by chi square.

Table 1

Hosmer and Lemeshow Goodness of Fit

\begin{tabular}{llll}
\multicolumn{4}{c}{ Test } \\
\cline { 1 - 3 } Step & $\begin{array}{l}\text { Chi- } \\
\text { square }\end{array}$ & Df & Sig \\
\hline $\mathbf{1}$ & 11.993 & 8 & .152 \\
\hline Based & on table & above & \\
& value
\end{tabular}

profitabilitas From Goodness of Fit Test Charge of $0.152>0.05$ Then it can be said a decent regression model for subsequent analysis.

\section{Overal Model Fit}

Uji overall model of fit Calculated from the difference in -2LL (Log Likelihood) Between models consisting of constants and independent variables. Test -2LL (Log likelihood) Following distribution chi square With degrees of freedom (degree of freedom).
Table 2

Iteration History ${ }^{\mathrm{a}, \mathrm{b}, \mathrm{c}}$

\begin{tabular}{|c|c|c|}
\hline \multirow{2}{*}{ Iteration } & \multirow{2}{*}{$\begin{array}{c}-2 \text { Log } \\
\text { Likelihood }\end{array}$} & \multirow{2}{*}{$\frac{\text { Coefficients }}{\text { Constants }}$} \\
\hline & & \\
\hline \multirow[t]{3}{*}{ Step 0} & 62.515 & .846 \\
\hline & 62.480 & .902 \\
\hline & 62.480 & .903 \\
\hline
\end{tabular}

a. Constants is included in the model

b. Initial -2 Log Likelihood ; 62.480

c. Estimation terminated at iteration Number 3 because parameter estimatedChanged by less than .001

Table 3 Iteration History $^{\mathrm{a}, \mathrm{b}, \mathrm{c}, \mathrm{d}}$

\begin{tabular}{|c|c|c|c|c|c|c|c|c|}
\hline \multirow{2}{*}{\multicolumn{2}{|c|}{ Iteration }} & \multirow{2}{*}{$\begin{array}{l}2 \text { Leg } \\
\text { Likeliheod }\end{array}$} & \multicolumn{6}{|c|}{ Corflkiknts } \\
\hline & & & Cotsian & $\mathrm{XI}$ & $\mathrm{X} 2$ & $\mathrm{X} 3$ & $\mathrm{X}_{4}$ & X5 \\
\hline \multirow{4}{*}{ Siep I } & 1 & 60.472 & 2.273 & 025 & 484 & 9070 &., 388 & .358 \\
\hline & 2 & 60.60 & 2606 & 035 & 610 & 115 & -485 & .449 \\
\hline & 3 & 60.302 & 2721 & 036 & 618 & .119 & -491 & $\cdot 455$ \\
\hline & 4 & 60.60 & 2721 & 0.6 & $61 \mathrm{k}$ & 119 & .401 & .459 \\
\hline \multicolumn{9}{|c|}{ a. Method: Einter } \\
\hline \multicolumn{9}{|c|}{ b. Cenceant is included in the model } \\
\hline \\
\hline \multicolumn{9}{|c|}{ comined } \\
\hline
\end{tabular}

Value -2 Log Likelihood Consisting of a constant of 62.480 , While the value $-2 \log$ Likelihood which includes free constants and variables of 60.302 .

Table 4

Omnibus Test Of Moel Coefficients Chi df Sig. Square

\begin{tabular}{ccccc}
\hline Step & Step & 2.178 & 5 & .000 \\
1 & & & & \\
& Block & 2.178 & 5 & .000 \\
& Model & 2.178 & 5 & .000 \\
\hline
\end{tabular}


The comparison follows the distribution chi square, Acquired value chi square Charge of 2.178 With df 5 , and acquired significance values of 0.000 Shows smaller than 5\% Then it can be concluded pressure (Financial targets), Opportunity (Effectiveness of surveillance), Rationalization (Auditor changes), competence (Change of Directors), and arrogance (Number of CEOS) Simultaneously affect the fraud of financial statements.

\section{Wald Test}

Hypothesis testing conducted individually or partially, testing conducted by inserting each independent variable conducted by inserting each independent variable.

Table 5. Wald Test

\begin{tabular}{|c|c|c|c|c|}
\hline & & Sig. & $\begin{array}{c}\operatorname{Exp}(\mathrm{B} \\
)\end{array}$ & $\begin{array}{l}\text { Descri } \\
\text { ption }\end{array}$ \\
\hline \multirow{7}{*}{$\begin{array}{l}\text { Step } \\
1^{\text {a }}\end{array}$} & Pressure & .76 & 1.037 & Rejecte \\
\hline & & 5 & & \\
\hline & Opportunity & $\begin{array}{c}.79 \\
6\end{array}$ & 1.854 & $\begin{array}{c}\text { Rejecte } \\
\mathrm{d}\end{array}$ \\
\hline & $\begin{array}{l}\text { Rationalizat } \\
\text { ion }\end{array}$ & $\begin{array}{c}.86 \\
2\end{array}$ & 1.127 & $\begin{array}{c}\text { Rejecte } \\
\mathrm{d}\end{array}$ \\
\hline & Competence & $\begin{array}{c}.46 \\
4\end{array}$ & .612 & $\begin{array}{c}\text { Rejecte } \\
\mathrm{d}\end{array}$ \\
\hline & Arrogance & $\begin{array}{c}.01 \\
0\end{array}$ & .634 & $\begin{array}{c}\text { Rejecte } \\
\mathrm{d}\end{array}$ \\
\hline & Contant & $\begin{array}{c}.16 \\
3\end{array}$ & $\begin{array}{c}15.19 \\
1\end{array}$ & \\
\hline
\end{tabular}

Variables (s) entered on step 1; X1.X2.X3,X4, X5

\section{Negelkerke R Square}

The coefficient of determination is used to know how large the variable variability of the dependent
Table 6 Coefficient Determination

\begin{tabular}{cccc}
\hline & $\begin{array}{c}\mathbf{- 2} \text { Log } \\
\text { Likelihood }\end{array}$ & $\begin{array}{c}\text { Cox \& } \\
\text { Snell R } \\
\text { Squaare }\end{array}$ & $\begin{array}{c}\text { Negelkerke } \\
\text { R Square }\end{array}$ \\
\hline $\mathbf{1}$ & $60.302^{\mathrm{a}}$ & .041 & .059 \\
\hline a. & $\begin{array}{l}\text { Estimation terminated at iteration } \\
\text { number 4 because parameter }\end{array}$ \\
& \begin{tabular}{l} 
estimates changed by les than .001. \\
\hline
\end{tabular}
\end{tabular}

Based on the test result coefficient of determination value on logistic regression indicated by the value Negekerke R Square Charge of 0.059 Which means that variable variable dependencies are described by dependent variables by $5.9 \%$. While the remaining $94.1 \%(100 \%-5.9 \%)$ other variables outside the research model. The value of $\mathrm{R}$ square is small due to other factors that influence the fraud of financial statements. Because in practice factors such as financial stability, personal financial need, liquidity, and auditor quality. The value of pressure, opportunity, rationalization, and insignificant competence also affects a small $\mathrm{R}$ square.

\section{Multikoleniaritas Test Results}

This test uses a correlation matrix between free variables to see the amount of correlation between free variables.

Table 7

Multikoleniaritas Test

\begin{tabular}{|c|c|c|c|c|c|}
\hline $\begin{array}{l}\text { Vari } \\
\text { able }\end{array}$ & $\begin{array}{l}\text { Toler } \\
\text { ance }\end{array}$ & $\begin{array}{c}\text { Term } \\
\text { s }\end{array}$ & VIF & Terms & $\begin{array}{c}\text { Descrip } \\
\text { tion }\end{array}$ \\
\hline $\begin{array}{c}\text { Press } \\
\text { ure }\end{array}$ & .957 & $>0.10$ & 1.044 & $<10$ & $\begin{array}{c}\text { Does not } \\
\text { occur } \\
\text { multikol } \\
\text { eniaritas }\end{array}$ \\
\hline $\begin{array}{l}\text { Opp } \\
\text { ortu } \\
\text { nity }\end{array}$ & .946 & $>0.10$ & 1.057 & $<10$ & $\begin{array}{c}\text { Does not } \\
\text { occur } \\
\text { multikol } \\
\text { eniaritas }\end{array}$ \\
\hline
\end{tabular}




\begin{tabular}{|c|c|c|c|c|c|}
\hline $\begin{array}{c}\text { Rati } \\
\text { onali } \\
\text { zatio } \\
\text { n }\end{array}$ & .946 & $>0.10$ & 1.057 & $<10$ & $\begin{array}{l}\text { Does not } \\
\text { occur } \\
\text { multikol } \\
\text { eniaritas }\end{array}$ \\
\hline $\begin{array}{l}\text { Com } \\
\text { pete } \\
\text { nce }\end{array}$ & .951 & $>0.10$ & 1.052 & $<10$ & $\begin{array}{l}\text { Does not } \\
\text { occur } \\
\text { multikol } \\
\text { eniaritas }\end{array}$ \\
\hline $\begin{array}{c}\text { Arro } \\
\text { ganc } \\
\text { e }\end{array}$ & .939 & $>0.10$ & 1.065 & $<10$ & $\begin{array}{l}\text { Does not } \\
\text { occur } \\
\text { multikol } \\
\text { eniaritas }\end{array}$ \\
\hline \multicolumn{6}{|c|}{ Dependent Variable : Cheating } \\
\hline
\end{tabular}

Value VIF Shown between the number1 and not exceeding the number 10 . Value tolerance Approaching numbers 1. Inconclusive regression model used free of multikoleniaritas.

\section{Matrik classification}

The Matrik classification shows the predictive power of the regression model to predict financial report fraud on the services companies of sub transportation, toll roads, airports, and ports.

Table 8

\section{Classification Matrix}

\begin{tabular}{|c|c|c|c|c|c|}
\hline & & & \multicolumn{3}{|c|}{ Predicated } \\
\hline \multicolumn{3}{|c|}{ Observation } & \multicolumn{2}{|c|}{ Cheating } & \multirow{2}{*}{$\begin{array}{c}\text { Percentage } \\
\text { Correct }\end{array}$} \\
\hline & & & 0 & 1 & \\
\hline Step & Cheating & 0 & 1 & 1 & 6.7 \\
\hline \multicolumn{6}{|l|}{1} \\
\hline & & 1 & 0 & 0 & 100.0 \\
\hline \multicolumn{3}{|c|}{ Overal Percentage } & & & 73.1 \\
\hline & The cut val & 500 & & & \\
\hline
\end{tabular}

Predictions of a model cheating report $100 \%$ Of the company that does not conduct a $6.7 \%$ Regression model used as many as 0 sub-sector services companies, toll roads, airports, and ports (6.7\%) The predicted not to do auditor switching. The prediction or determination of the model in clarifying its obsrvation $73.1 \%$.

\section{Logistics Regression test Results}

\section{Tabel 9}

Variables in the Equation

\begin{tabular}{lcc}
\hline Description & $\begin{array}{c}\text { B (Regression } \\
\text { coefficient) }\end{array}$ & S.E. \\
\hline Pressure & .036 & \\
Opportunity & .618 & \\
Rationalizati & .119 & \\
on & & \\
Competence & -.491 & \\
Arrogance & -.455 & \\
Constant & 2.721 & 1.950 \\
\hline
\end{tabular}

Based on the results of logistic regression test, hence acquired regression equation :

$$
\mathrm{Y}=\begin{aligned}
& 2.721+0.036+0.618+0.119-0.491- \\
& 0.455+1.950
\end{aligned}
$$

\section{DISCUSSION}

Based on the research results can be known hypothesis 1 Variable Pressure (Financial targets) No effect on fraudulent financial statements. It is in accordance with the research conducted Hanifa (2015) Financial targets have no effect on the fraud of the Quisition report, financial targets determined by the board or management including sales targets and isentif magnitudes.

Based on hypothesis testing results 2 Regression coefficient for variables Opportunity (Financial targets) No effect on fraudulent financial statements. This research is in line with research conducted Yuniatie (2017) Surveillance effectiveness includes the examination and the set plans 
are already running properly and measure the success of the company's performance in achieving the objectives.

Based on hypothesis testing results 3 rationalization (Auditor changes) Have no effect on the cheating report. This research is consistent with research conducted Harto (2016) Changes in auditors are not concerned against the fraud of financial statements, the company replaces the External Auditor because it is not satisfied with the performance of the auditor from the previous period. In addition, the company replaced the auditor due to government Regulation No 20 year 2015 stated the provision of audit servicesFinancial Statements for an entity maximum five years in a row.

Hypotheses test Results 4 Indicates that the competence (Change of Directors) No effect on fraudulent financial statements. This research is in line with research Aulia (2018) Change of directors does not affect the fraud of financial statements. Change of Board of Directors due to new board of directors in accordance with employee selection standards

Hypotheses test Results 5 Indicates that the arrogance (Number of CEOS) Financial statements of the company. Research in line with research Hartoyo (2016) frequent number of CEO pictur affect financial fraud. Professional attitude towards corporate responsibility arrogance which has greedy properties, if good internal control of fraudulent action that would harm the company can be controlled. Rationally if there is an person CEO able to make cheating then other CEOs can evaluate actions that would harm other parties.

\section{CONCLUSION}

The first hypothesis test results in explaining that pressure (financial target) is not Influential To Kecurnagan financial statements, this is because the financial target is determined by the Board, including the sales objectives and the size of the incentive to be given, so that management performs its obligations and displays the best performance. The second hypothesis of the test shows that opportunity has no effect on the financial report fraud, the supervision of the Commissioners is very limited because in the scope of the management there is a position that gives the opportunity to do fraud. The third hypothesis test results indicate rationalization (changes in the auditor) has no effect on the fraud of financial statements, the Government regulation on the rotation of the auditor's profession forced the company to replace the auditor within the government's predetermined time. The results of the fourth hypothesis testing competence (change of Directors) has no effect on the fraud of the company's financial statements, the decision of change of directors will provide a positive effect for the company's performance, the new directors will give the company a better change The results of the fifth hypothesis test show arrogance (number of the CEO) affect the fraud of financial statements, the number of CEO makes an indication of the company's insecurity attitude superiority and differences in interest triggers the $\mathrm{CEO}$ to perform fraudulent actions. 


\section{RECOMMENDATION}

Further research can increase the number of research samples so that the research results can represent the entire service company. From the results of this study obtained Negelkerke R Square value of $5.9 \%$ which means there is still $94.1 \%$ that can affect the dependent variable. Then in subsequent studies can be excavated more deeply on other fakors that affect the dependent variables of fraud financial statements such as financial stability, personal financial need, liquidity, and quality auditors.

\section{REFERENCESS}

Aulia, H. (2018). ANALISIS FRAUD

DIAMOND DALAM

MENDETEKSI POTENSI

KECURANGAN LAPORAN

KEUANGAN. Journal of Financial

Crime, Vol 6 No 5, 78-80 ISSN:

2395-7492.

Beneish, M. D. (1999). The detection of earnings manipulation. Financial

Ananlysts Journal , 24-36.

Cressey, D. (1953). Other People Money A

Study in teh Social Phycology of

Embezzlement. MontchlainJN:

Patterson Smith .

Crowe. (2011). Why The Fraud Triangle is

no Longer Enought in horwarth

crowe LLp.

Damyanti Fitri., W. T. (2017). Pengaruh

Faud Pentagon terhadap

Kecurangan Laporan Keuangan

pada Perusahaan Infrastruktur. jurnal akuntasi dan bisnis, Vol. 11. No. 6.

Harto, t. G. (2016). Fraudulent Financial Reporting : Pengujiam Teori Fraud Pentagon pada Sektor Keunagan dan Perbankan di Indonesia. journal of akademic research in accounting finance, Vol 5 No 4, pp, 38-45.

Hartoyo. (2016). pentagon fraud dalam mendeteksi fraudulent financial reporting pada perusahaan manufaktur yang terdaftar di bursa efek indonesia periode 2011-2015.

husnawati, p. (2017). penipuan Pentagon Analisis di Menilai Kemungkinan penipuan Pentagon Analisis di Menilai Kemungkinan Laporan Keuangan Penipuan . ISSN: 25982532 .

Kinanti, M. A. (2018). MODEL BENEISH

M-SCORE UNTUK MENDETEKSI KECURANGAN PADA OERUSAHAAN PERBANKAN. Jurnal optimum, Volume.8, No. 2.

Mark F. Zimbelman, C. C. (2014). Forensic Accounting . Singapore: Cengage Learning.

Marks, J. (2012). The Mind Behind The fraudsters Crime: key Behavioral and Enviromental Elements . Crow Howard LLP (presentation).

Marks, Z. F., Connan, A. C., Albrecht, W. S., \& Albrecht, C. O. (2014).

Forensic Accounting. Sinngapore: CENGAGE Learning.

Martantya, D. (2015). PENDETEKSIAN KECURANGAN LAPORAN KEUANGAN MELALUI FAKTOR RISIKO TEKANAN 
P-ISSN : 2655-3651

E-ISSN : 2656-0435

DAN PELUANG. Majalah Ilmiah

Bijak journal, Vol. 16, No. 2.

Massod, B. (1999). The detection of

Earnings Manipulation. Financial

Analysts Journal , Vol. 14, Issue 5

ISSN 2550-1267.

Sekar, F. A. (2016). FRAUD PENTAGON

DAN KECURANGAN LAPORAN

KEUANGAN . Jurnal Ekonomi dan

Bisnis, ISSN 2549-4988.

Yuniatie. E, D. F. (2017). PENGARUH

FRAUD PENTAGON TERHADAP

KECURANGAN LAPORAN

KEUANGAN PADA

PERUSAHAAN

INFRASTRUKTUR

YANGTERDAFTAR DI BURSA

EFEK INDONESIATAHUN 2014

- 2016. Jurnal Ilmu dan Riset

Akuntansi, Volume 5, Nomor 5, ISSN : 2460-0585. 